ESJ Social Sciences

\title{
Theoretical Review of the Impact of Fiscal Deficits on Economic Growth in Nigeria
}

\author{
Bushi Kasimu Musa (M.SC. /MBA/PhD in View) \\ Independent Researcher and Consultant
}

Doi:10.19044/esj.2021.v17n1p310

Submitted: 05 June 2020

Accepted: 04 January 2021

Published: 31 January 2021
Copyright 2021 Author(s)

Under Creative Commons BY-NC-ND

4.0 OPEN ACCESS

Cite As:

Musa K.B. (2021). Theoretical Review of the Impact of Fiscal Deficits on Economic Growth in Nigeria. European Scientific Journal, ESJ, 17(1), 310.

https://doi.org/10.19044/esj.2021.v17n1p310

\begin{abstract}
The growth and persistence of fiscal deficits in both the industrialized and developing countries has brought the issue of fiscal deficits into sharp focus. Over the last decade, the growth impact of fiscal deficits has generated large volume of both theoretical and empirical literature. Despite the lofty place of fiscal policy in the management of the economy, the Nigerian economy is yet to come on the path of sound growth and development. The behaviour of fiscal deficits in Nigeria has followed unsteady pattern, assessing the significance of the policy deficits. The actualization of sustainable economic growth is more imperative such that the country is working towards achieving the sustainable development goals. The paper adopted a descriptive method to show the trend of fiscal elements in Nigeria with the aim of determining the relationship between the variables specified. The paper concludes that fiscal operation is ineffective in providing the needed macroeconomic environment for sustainable growth. This paper further suggests that powerful pro-stability stakeholders strong enough to challenge government fiscal recklessness will need to emerge for sustainable and progressive development to be attained at all levels.
\end{abstract}

Keywords: Fiscal deficits, Economic growth, Government spending, budget deficits 


\section{Introduction}

Fiscal policy simply refers to actions taken by government with a view to controlling government expenditure and income in order to achieve some predetermined macro-economic objectives. These objectives include, but are not limited to reduction in unemployment level, price stability, rapid economic development, and a healthy balance of payments position (Abdurrauf, 2015). In developing countries, fiscal policy is regarded as a tool for moving backward economies to the path of sustained economic growth and development. The fiscal system is generally viewed as one with a package of instruments for translating development policy objectives into practice. One of such package of instruments is fiscal deficits.

Furthermore, it involves the use of government spending, taxation, and borrowing to influence the pattern of economic activities and also the level and growth of aggregate demand, output, and employment. Fiscal policy entails government's management of the economy through the manipulation of its income and spending to achieve certain desired macroeconomic objectives (goals) amongst which is economic growth (Medee \& Nembee, 2011). Olawunmi and Tajudeen (2007) opine that fiscal policy has conventionally been associated with the use of taxation and public expenditure to influence the level of economic activities. They further say that the implementation of fiscal policy is essentially routed through government's budget. Fiscal policy is used mostly to achieve macroeconomic policy and to reconcile the changes which government modifies in taxation, expenditure, and programmes or to regulate the full employment price and total demand to be used through instruments such as government expenditures, taxation, and debt management (Hottz-Eakin, Lovely \& Tosin, 2009). As noted by Anyanwu (1993), the objective of fiscal policy is to promote economic conditions conducive to business growth while ensuring that any such government actions are consistent with economic stability. From the foregoing, it is clear that if fiscal policy is used with circumspection and synchronized with other measures, it will likely smoothen out business cycles and lead to economic growth and stability.

In principle, fiscal dominance occurs when fiscal policy is set exogenously to monetary policy in an environment where there is a limit to the amount of government debt that can be held by the public. Hence if the inter-temporal budget constraint must be satisfied, fiscal deficits would have to be magnetized sooner or later. In fact when the size of the financial system is small relative to the size of the fiscal deficits, a central bank may have no choice but to magnetize the deficits. Thus, in countries with shallow financial systems, monetary policy is the reverse side of the coin of fiscal policy and can only play an accommodative role. In such low income countries, government securities markets are underdeveloped and central banks do not 
hold sufficient amounts of tangible securities. Also, the central bank's lack of suitable and adequate instruments of monetary control constitutes one of the factors that induce fiscal dominance.... Where fiscal dominance applies, the country's economic policy is only as good as its fiscal policy and institutionalized central bank independence may not necessarily bring about an independent monetary policy (Oyejide, 2003).

\section{Fiscal Deficits in Nigeria (1980 - 2019)}

In Nigeria, fiscal expenditure is made possible by unprecedented earnings from oil sales which most often than not is alternated by periods of oil glut that leads to significant declines in government revenues. The custom of fiscal deficits in Nigeria is that it is skewed heavily in favour of recurrent expenditure (60 percent recurrent expenditure and 40 percent capital expenditure) which does not necessarily drive economic development. Since one of the critical instruments of fiscal policy is fiscal deficits, hence, stabilization of prices, growth of per capita income, and employment requires that fiscal deficit itself must grow or expand at a low constant rate. Fiscal deficits have been growing at a rate that is alarmingly not constant. As can be observed in Table 1, the growth rate of fiscal deficits rose from 97.55 percent in 1981 to 171.54 percent in 1986 and rose to 3104.94 percent in 1996 respectively. Fiscal deficit growth rate was negative (- 115.60 percent) in 1997, but increased steadily to 2567.78 percent in 1998 and declined to 2.07 percent in 2016. It also rose to 109.42 in 2017. In 2018 and 2019, there was a decline of 33.53 and 25.95, respectively. Between 1998 and 2019, the deficit growth rate has been rising and falling. Thus, this indicates that fiscal deficit has not been growing at a constant rate.

Table 1. Fiscal deficit growth rate in Nigeria from 1980-2020

\begin{tabular}{|l|l|l|}
\hline Year & Fiscal Deficit (N' Billion) & $\begin{array}{l}\text { Growth Rate of Fiscal } \\
\text { Deficit (\%) }\end{array}$ \\
\hline 1980 & -1975.2 & - \\
\hline 1981 & -3902.1 & 97.55 \\
\hline 1982 & -6104.1 & 56.43 \\
\hline 1983 & -3364.5 & -44.88 \\
\hline 1984 & -2660.4 & -20.92 \\
\hline 1985 & -3039.7 & 14.25 \\
\hline 1986 & -8254.3 & 171.54 \\
\hline 1987 & -5889.7 & -28.64 \\
\hline 1989 & -12160.9 & 106.47 \\
\hline 1990 & -15134.7 & 24.45 \\
\hline 1991 & -22116.1 & 46.12 \\
\hline 1992 & -35755. & 261.67 \\
\hline 1993 & -39532.5 & 10.56 \\
\hline 1994 & -107735.3 & 172.52 \\
\hline & -70270.6 & -34.77 \\
\hline
\end{tabular}




\begin{tabular}{|l|l|l|}
\hline 1995 & 1000.0 & -101.42 \\
\hline 1996 & 32049.4 & 3104.94 \\
\hline 1997 & -5000.0 & -115.60 \\
\hline 1998 & -133389.3 & 2567.78 \\
\hline 1999 & -285104.7 & 113.73 \\
\hline 2000 & -103777.3 & -63.60 \\
\hline 2002 & -221048.9 & 113.0 \\
\hline 2003 & -301401.6 & 36.35 \\
\hline 2004 & -202724.7 & -32.73 \\
\hline 2005 & -172601.3 & -14.85 \\
\hline 2006 & -161406.3 & -6.48 \\
\hline 2007 & -101397.5 & -37.17 \\
\hline 2008 & -117.2 & -99.88 \\
\hline 2009 & -47.3 & -59.64 \\
\hline 2010 & -810.0 & 1612.47 \\
\hline 2011 & -110.5 & -86.35 \\
\hline 2012 & -115.8 & 4.79 \\
\hline 2013 & -975.6 & 742.48 \\
\hline 2014 & -115.3 & -88.18 \\
\hline 2015 & -1064.6 & 823.33 \\
\hline 2016 & -1109.0 & 4.17 \\
\hline 2017 & -1085.8 & -2.09 \\
\hline 2018 & $-2,273.9$ & 109.42 \\
\hline 2019 & $-3,421.0$ & 33.53 \\
\hline & $-4,620.0$ & 25.95 \\
\hline & & \\
\hline
\end{tabular}

Source: Authors' computation based on CBN Statistical Bulletin 2019

\section{Objectives of the Study}

The central purpose of this study is to theoretically investigate the effect of deficit financing on Gross Domestic Product (proxy for economic growth) in Nigeria over the period of 1981 to 2019. Thus, the specific purpose includes;

1. To examine the effect of Fiscal deficits on Nigerian economic growth.

2. The study stands to enlighten policy makers on the ways of finding the best policy to use deficit financing matter.

3. The study will help investors to realize the actual state of the economy.

4. Researchers will find it rewarding as it will add to the rich collection of work in available literatures due to the timeliness of the write up.

5. The study helps to reveal the stand of the economy in the face of deficit deficits.

\section{Theoretical Foundation}

Fiscal deficit is considered as the major phenomenon in the economic world of today. Quite a lot of empirical and conceptual literatures with 
conflicting results have continued to surface on how fiscal operations can affect macroeconomic activities both in the short-run and long-run.

\subsection{Keynesian Theory}

This theory is also referred to as Income Expenditure Approach and Conventional Approach. According to Keynesian approach, fiscal deficit positively affects growth. There would be an increase in government outlays due to addition in money supply which explains how addition in money supply comes about. There is relative short fall of demand in accordance with money supply. The lending rate will decrease as a result of increased money supply. Investment will increase especially in private sector due to incentive of reduced lending rate. Keynesian multiplier will work and investment will increase. As investment increases, the output capacity will be enhanced. Keynesian theory also provides the room for crowding out private investment. If fiscal deficit is financed through debt instrument, then there will be increase in lending rate and private investment will be crowded out due to limited availability of finance (Saleh, 2003). By putting increase in money supply and crowding out effect together, the positive effect of fiscal deficit on growth gets obscured. The Keynesians further posit that fiscal deficits could have a negative impact on the external sector, reflected through trade deficit, but only if the domestic economy is unable to absorb the additional liquidity through an expansion in output. Hence, if the supply of output does not expand in response to the deficit, the surplus spending would only add to the level of imports, thereby resulting in a trade deficit and subsequent decrease in the exchange rate: "the twin-deficits" hypothesis (Monacelli \& Perotti, 2006; Neaime, 2008; Okpanachi \& Abimiku, 2007).

\subsection{Monetarist Theory}

According to monetarists, government deficits, financed by domestic debt, only involves transferring funds to public sector from the private sector with no effect on output. The private sector is more efficient than the government sector. Thus, such a transfer could have a negative effect on output. The monetarists argue that monetary financing affects the economy by increasing aggregate demand (Mitchell, 2002; Okpanachi \& Abimiku, 2007). Debt financing of fiscal deficit raises the interest rate and leads to decrease in investment which as a result decreases economic growth (Chakraborty \& Chakraborty, 2006).

\subsection{Neo-classical Theory}

According to this theory, fiscal deficits raise aggregate consumption in the economy which brings a reduction in national savings, and a higher real interest rate will generate incomplete sentence (in a closed economy). This, in 
turn, negatively affects investment and overall economic activity. Increase in fiscal deficit causes increase in capital flows which leads to appreciation of exchange rate in an open economy. In both cases, crowding out investment (how?) and reduction in net exports are the results of increased fiscal deficit. The crowding out investment and existence of external debt has adverse consequences for future output.

\subsection{Endogenous Growth Theory}

The endogenous growth theory proposes that economic growth is an endogenous outcome of the system. Since growth is endogenous, government policies can influence its magnitude and the government plays a vital role in economic development. Capital formation in physical assets of a country, human capital formation and public investment in areas such as infrastructure, and science and technology wields a positive impact on output. Similarly, government policies about law and order situation and the economized taxation system encourage growth in an endogenous manner. Thus, unlike other theories, the fiscal policy can affect long run growth performance if growth is considered as an endogenous variable (Saleh, 2003). Hence, this theory can be placed in the context of fiscal deficit.

\subsection{Sargent and Wallace Hypothesis}

According to this hypothesis, fiscal deficit affects output growth through two channels. First, fiscal deficit affects money growth through its financing. When funds are generated by increasing money supply, the surplus money may not be absorbed by the economy due to shortage of aggregate supply. The increased demand may push the general price level which may result in inflation. Second, inflation generated from increased money growth may affect output growth negatively by rising cost of production and a decrease in aggregate supply (Lozano, 2008).

\subsection{Golden Rule of Public Finance (GRPF)}

The rule states that government adopts fiscal deficit if the deficit is used for productive and profitable investment projects. The rule can generate less balanced growth in the long run. In the short run, its results are dependent on the initial level of public debt. GPRF states that funds used for productive projects may generate growth in both periods so deficit budget is acceptable. Adoption of GPRF for an economy depends on the original level of public debt. As for short run results, country's debt situation may be considered due to external debt (Ismihan \& Özkan, 2012). 


\subsection{The Tax and Spend Hypothesis}

According to this hypothesis, the policy of government to increase taxes for reducing deficits would result in decrease in private consumption, and politicians would encourage increasing their expenditure while deficit would remain same in long run. On the other side, if deficit is financed by tax cut, there would be pressure on government spending but it would increase private consumption without changing the budget deficit and national savings. This would be more desirable as compared to tax increase. The deficit has to run if government expenditure does not decrease because there would be addition in the interest payments (Chang \& Ho, 2002). In a nutshell, various theories describe the transmission mechanism of fiscal deficit for affecting the economy. According to these theories, fiscal deficit may have positive, negative or neutral effects on economic activities.

\section{Appraising Keynesian Proposition and Classical Proposition Along Emprical Research}

\subsection{Keynesian Proposition}

Relevant works in the literature related to the Keynesian propositions includes the following contributions: Onyemaechi (2014) examines the impact of fiscal deficits components on economic growth in Nigeria from 1980 to 2010 using a baseline, log and lag models of regression analysis. The result shows that the effect of fiscal policy component (government expenditure) on economic growth at a certain level appeared to be statistically insignificant. However, public sector expenditures on administration, social, and community services produce positive effects on growth. Similarly, Agu et al. (2014) evaluated the relationship between fiscal policy components and economic growth in Nigeria from 1961 to 2010 using OLS in multiple regression frameworks. The study establishes the existence of a positive and significant correlation between economic growth and the components of fiscal policy. Though investment spending appeared very insignificant compared to recurrent expenditure, hitherto, aggregate government spending tends to increase with tax revenue, with spending increasing faster than the tax revenue. Likewise, empirical results from Mansouri (2008) in a study that examined the effect of fiscal policy in Egypt, Tunisia, and Morocco based on error correction model and log-linear regression model argue that public investment exerts a crowding-in effect on economic growth. Further evidence shows a significant relationship between productive expenditure on investment and economic growth in all the three countries. Thus, such kind of public spending exercises a positive impact on growth. In order to adjust the public sector budget, fiscal adjustment should be concentrated on reducing wasteful expenditure which appeared as an obstacle to economic growth in the study countries. In addition, Fatas and Mihov (2001) evaluate the effects of 
fiscal policy on macroeconomic growth in developed countries by utilising a quarterly data from 1960Q1 to 1996Q4. The study adopts a VAR technique. Findings reveal that increase in public consumption is accompanied by a corresponding increase in consumption, employment and output, while the increase in government investment does not affect public spending significantly. This, however, supports the argument that fiscal policy exerts a positive influence on the real output growth within the review period.

Equally, Maku (2015) evaluates the effects of fiscal deficits on economic growth in Nigeria from 1970 to 2011 using Engle-Granger cointegration test and OLS estimation model. The study submitted that a fiscal deficit is generally believed to be associated with growth. Alternatively, it is believed that appropriate fiscal measures in a particular circumstance can be used to encourage growth. The result from the estimation shows that fiscal deficits rather than monetary produces a higher influence on the nation's economic growth and development. In a similar analysis, using cointegration technique and a Vector Error Correction Model (VECM), Byiabani and Mohseni (2014) examine the effects of fiscal deficits and economic growth in Iran over a period of two decades. The study argued that there exists a positive and significant long-run relationship between economic growth and fiscal deficits components, including government investment and private investment, labour force, and human capital stock. In another development, Yadav et al. (2010) investigate the impact of fiscal deficits in India using a Structural VAR (SVAR) on quarterly data from 1997Q1 to 2009Q2.

Finding reveals that the effects of fiscal shocks to government expenditure on private consumption produce a positive impact, while shock on the tax to private consumption yield negative results on the nation's growth. Furthermore, Jemec et al. (2011) examine how fiscal shocks affect macroeconomic dynamics in Slovenia using a SVAR technique adopted from Blanchard and Perroti (2002) on quarterly data from 1995Q1 to 2010Q4. The study maintained that government fiscal deficits increase output growth, investment, and private consumption only in the short-run. On the other hand, tax shocks are found to decrease output growth, investment, and private consumption. In the long-run, the effects of both spending and tax would become insignificant, respectively. The results indicate that fiscal policies have weak impact multipliers. In other word, changes in government spending and taxes do not have longrun effects on macroeconomic variables. Alex and Ebieri (2014) examine the impact of fiscal deficits on economic growth in Nigeria from 1986 to 2010 by employing an Autoregressive Distributed Model (ARDL) and log-linear model of the multivariate regression model.

The study empirically established that about $69 \%$ of the total variation in the real GDP is explained by fiscal policy variables. Total government expenditure as a fiscal policy variable has more positive and significant impact 
on GDP than non-oil tax and total debt. Hence, there is an evidence of longrun equilibrium relationship between fiscal policy and economic growth in Nigeria. Likewise, empirical results from Nathan (2012) in a study that examines the impact of fiscal policy in Nigeria from 1970 to 2010 using error correction model and two-band recursive least square technique reveals a significant causal relationship between GDP and fiscal policy variables. Hence, fiscal operations have a positive influence on output growth in the Nigerian economy. Furthermore, Cyril (2016) examines the influence of fiscal policy on real output growth in developing countries from 1986 to 2013 using an OLS estimation technique. Finding reveals that fiscal policy components, particularly public spending on economic services, have enormous returns to economic growth and stability. The results further propose that these expenditures crowd-in private investment. Therefore, there is an evidence of a positive relationship between public spending on economic services and economic growth. In other words, an increase in budgetary allocation to economic services will lead to a speedy improvement in economic stability. Moreover, Imoisi (2013) examine the implication of fiscal policy measures on the Nigerian economy from 1970 to 2009 using the OLS of multiple regression models. The study maintained that fiscal policy is a strong determinant of economic growth, particularly when aggregate public sector expenditure is properly directed towards the provision of adequate basic infrastructural facilities to encourage private sector participation and stabilise investment activities in the economy. In a similar submission, Ogbole et al. (2011) evaluate the causal link between fiscal policy and economic growth in Nigeria from 1970 to 2006 using a granger causality test and Johansen cointegration technique. The study supported that fiscal policy operation, though insignificant, has a positive impact on the macroeconomic stability. The study further reveals the existence of a causal relationship between fiscal policy components and GDP with a unidirectional causality running from aggregate expenditure to GDP. In addition, Appah (2010) investigates the relationship between fiscal policy and economic growth in Nigeria from 1991 to 2005 using OLS multiple regression analysis. The result indicates a significant positive relationship between fiscal policy components and Gross Domestic Product (GDP), and no relationship exists between the specific explanatory variables contributing to GDP except the aggregate government spending. On the average, $99 \%$ of the total variations in GDP are explained by fiscal components in the model.

Moreover, Mathew (2011) examines the effect of fiscal policy on economic growth in South Africa using a quarterly data from 1990Q1 to 2008Q4 by adopting a SVAR model of Blanchard and Perroti (2002). The result supports the arguments that the effect of fiscal policy on real output tends to be uncertain, though persistent and significant through shocks on 
public consumption expenditure, public investment expenditure, tax revenue, and budget deficits. Though the effect is positive for shocks from tax revenues and budget deficit, it is negative from public sector consumption and investment expenditures. Similarly, Zhattau (2013) conceptually assess the role of fiscal policy in influencing output growth in Nigeria by using a descriptive analysis. The study supports the arguments that fiscal policy plays a vital role in ensuring economic growth and stability. Therefore, an appropriate system of tax implementation will increase the revenue generating capacity of a country thereby accelerating economic growth. The study further submits that the efficiency of the tax system is not just an issue of appropriate tax laws, but it is also the efficiency and integrity of the tax administrators. Likewise, Musa, Asare and Gulumbe (2013) analyse the effects of fiscal and monetary policy interaction on output growth in Nigeria from 1970 to 2010 using VAR methodology. The result shows a positive relationship between fiscal policy components and output growth. Thus, this implies that public revenue as a fiscal policy variable has a significant influence on the economic growth and also leads to an increase in price. This is because the spending decision of the public sector is significantly determined by the aggregate government revenue. Similarly, Arestis (2009) examines the effects of a new consensus in macroeconomics in relation to fiscal and monetary policy in developed countries by utilising a general equilibrium model. The study debated that fiscal policy operations has a significant impact on the economic growth, and it also serves as an effective instrument for regulating the level of aggregate demand in an economy. Moreover, evidence was revealed by Abdurrauf (2015) in a study that evaluated the impact of fiscal policy on economic development in Nigeria from 1981 to 2013 by employing pair wise correlation test. VECM and Johansen cointegration test shows that aggregate public expenditure and government investment have a positive and significant effects on economic development, whereas tax revenue produces a negative effects both in the short-run and long-run. In addition, empirical findings from Babalola and Aminu (2015) in a study that examines the relationship between fiscal policy and economic growth in Nigeria using VECM and Engle-Granger cointegration test indicates a long-run relationship between government expenditure and economic growth as revealed by the cointegration result.

Consequently, this means that productive government spending has a positive and significant impact on economic growth during the study coverage period 1977 to 2009 . This result is similar and consistent with the study findings revealed by Austin and Ogbole (2014) in Nigeria from 1970 to 2010 using a granger causality technique. Furthermore, Osinowo (2015) examines the effect of fiscal policy on sectoral output in Nigeria from 1970 to 2013 by employing ARDL and Error Correction Model (ECM). The study debated that different fiscal policy variables, to a considerable extent, have a significant 
influence on the output growth. Generally, the study holds the view that aggregate government spending has a positive relationship with sectoral output, i.e., economic growth. Therefore, inflation serves as a major brake on output growth among the various sectors of the economy within the sample period. In the same vein, Gemmell and $\mathrm{Au}$ (2012) evaluated the relationship between fiscal policy and output growth in OECD countries from 1995 to 2009 using a pooled regression model. The study found that, among other things, increase in government spending as a fiscal policy variable has a positive effect on output growth while increased tax rates produce a negative effect in all the review countries. In addition, Kilindo (1997), Tanzi and Howell (1997), Easterly and Rebelo (1993), Baxter and King (1993), and Engen and Skinner (1992) postulated that fiscal policy and its various components play a fundamental role in influencing the long-run growth performance of an economy.

\subsection{Classical Proposition Literature}

Classical proposition includes the following contributions: Baunsgaard (2003) examines the role of an appropriate fiscal policy rule in macroeconomic growth in Nigeria from 1970 to 2001 using a simulation analysis. The study debated that fiscal operation exerts negative influences on output growth since both revenue and expenditure were highly volatile. In other words, a major challenge for the economy is the macroeconomic volatility both in terms of expenditure and revenue driven largely by external terms of trade shocks, weak fiscal discipline, and the nation's heavy dependence on oil export earnings. Furthermore, empirical support from Ilzetzki et al. (2011) contribute to the literature by examining the effect of fiscal multipliers on 44 countries (20 developed and 24 developing) using a quarterly data set from 1960Q1 to 2007Q4. The study employed a SVAR technique originally developed by Blanchard and Perotti (2002). Hence, the finding shows that the response of economic growth due to increase in public expenditure is larger among industrialised countries than in developing countries. In addition, the framework of fiscal policy differs among developing countries not only in its execution but in its effects and relationship with other policies. This is because the increase in government expenditure is far more short-lived compared to highly-persistent public expenditure shocks in developed countries. A similar result is obtained by Ravn and Spange (2012) in Denmark using a SVAR model as developed by Blanchard and Perotti (2002) from 1983 to 2011. In another related development, Abata, Kehinde and Bolarinwa (2012) evaluate the influence of both monetary and fiscal policy variables on economic growth using a theoretical exploration. The study submitted that the role of fiscal policy in achieving sustainable economic growth has remained a mirage. In spite of a considerable increase in 
the public sector spending over the years, the growth rate remains very low. Further evidence reveals that the effect of monetary policy on economic growth is much stronger than that of fiscal policy within the review period. This finding is consistent with the results obtained by Ajisafe and Folorunso (2002) amd Adefeso and Mobolaji (2010). Blake (2013) measures the impact of fiscal multipliers on Jamaican government by adopting a SVAR technique from Blanchard and Perotti (2002). The study employed quarterly data from 1993Q2 to 2012Q2, and the results indicate that the effects of fiscal policy (expansionary) on GDP are weak and not persistent. Fiscal policy produces insignificant effects on growth, especially in the long run, because the fiscal multiplier is statistically insignificant on impact and zero over the long run. In addition, Perotti (2002) examines the effects of fiscal policy in five (5) OECD countries using a quarterly data from 1960Q1 to 2001Q4 by utilising Structural VAR (SVAR) technique. The study holds the view that, in the last 20 years, the effects of fiscal policy on growth and its various components appeared significantly very weak in OECD countries, hence, providing less support for a long-run relationship between fiscal policy and economic growth. Furthermore, Akanni and Osinowo (2013) examine the effect of fiscal instability on output growth in Nigeria from 1970 to 2010 using CUSUM of square diagnostic test and the Hodrick-Prescott (HP)-filtered fiscal framework with correlation technique. The result shows that fiscal policy component (aggregate government expenditure) has a negative and insignificant effect on economic growth.

Connecting the discussion in this paragraph to fiscal deficits from a disaggregated level, capital expenditure is also found to be negative while recurrent is positive. Nevertheless, labour force and trade openness have a significant countercyclical effect on the economy over the review period. In the same vein, Nelson and Singh (1998) investigate the relation between fiscal policy, economic freedom, and output growth in LDCs from 1970 to 1989 using a neoclassical growth model. The study concluded that the large government expenditure is detrimental to a nation's growth, but economic freedom shows a positive and significant effect on economic growth. Evidence of government policy and economic freedom variables obviously submits that many heroes of dictatorship wrongly attribute the poor economic performance to democracy when in reality it is public sector policies that may be responsible for poor growth in such respective countries. Similarly, Enache (2009) investigates the relationship between fiscal policy and economic growth in Romania using forecasted time series data from 1992 to 2013 by using a reduced-form neoclassical growth model to develop a regression analysis for the estimation. The results established a weak evidence for the positive impact of fiscal policy on economic growth, and a decrease of distortionary government revenues accompanied by a reduction in 
unproductive government spending will increase real output growth in the long run. In addition to these, empirical evidence is supported by Havi and Enu (2014). The paper examines the effect of fiscal and monetary policy in the economy of Ghana from 1980 to 2012 using an OLS estimation technique. Results show that fiscal policy is insignificant compared to monetary policy in achieving sound and sustainable macroeconomic growth.

\section{Review of Fiscal Deficit in Nigeria}

From the fabrics of the two divergent opinions, the Nigerian economy is a battle ground or peaceful ground depending on one's disposition. Despite these discernable views, government expenditures can breed economic growth in Nigeria. This position was earlier supported by some eminent scholars like Baro (1990), Chenery and Syrquin (1975), Landu (1983), Diamond (1990), Longe (1984), Odusola (1996), and Ekpo (1995). Baro (1990) was among the first to formally endogenize government spending in a growth-model and to analyze the relationship between size of government and the rate of growth and saving. He concluded that an increase in the resources devoted to nonproductive government services is associated with low capital. From an allocating perspective, an increase in government consumption leads to capital formation or private consumption. Some development economists of the Structuralist School prove that some categories of government expenditures are necessary to overcome constraints to economic growth (Chenery \& Syrquin, 1975). In the seminal work of Landau (1983), the share of government consumption to GDP reduces economic growth. This is consistent with the pro-market view that the growth in government constrains the overall economic growth. Diamond (1990) notes that in Nigeria, less attention has been given to examining the productiveness of the various components of public spending. Longe (1984) examines the growth and structure of government expenditures in Nigeria with a view of ascertaining if the pattern fits with the results of other countries. Thus, his study revealed that government expenditure has shown many considerable structural shifts over the review period and that the ratio of government expenditure to GNP has been rising and corresponds with the rising share hypothesis. Odusola (1996) adopts a simultaneous equation model to capture the interrelationship between government expenditure and economic growth in Nigeria.

The role of government sector in economic management is performed through the formulation and implementation of economic policy generally and fiscal policy in particular. It is designed to achieve the objective of price stability, growth, balance of payments equilibrium, full employment, mobilization of resources, and investment. These objectives have influenced government's economic policy design and development efforts in Nigeria since independence. Different opinions have indeed continued to emerge on 
how fiscal policy can affect economic activities. The genesis of these controversies has been traced to the theoretical exposition of the different schools of thought, namely: the Classical, the Keynesian, and the Neoclassical schools of thought. To the Classical school of thought, fiscal deficits incessantly financed by debt crowds-out private investment and by extension lower the level of economic growth.

According toTchokote (2001), the classical economists believe that debt issued by the public has no effect on the private sector savings. To them, a deficit financed by increasing the supply of securities, ceteris paribus reduces its price and raises real interest rates and this crowds out private investment. In sum, excessive deficit can lead to poor economic performance. Omitogun and Ayinla (2007) noted that the Keynesian school of thought postulates a positive relationship between deficit financing and investment and consequently on economic growth. This school of thought sees fiscal policy as a tool for overcoming fluctuations in the economy. Argumentatively, Tchokote (2001) noted that this school regards deficit financing as an important tool to achieve a level of aggregate demand that is consistent with full employment. When debt is used to finance government expenditures, consumers' income will be increased. Given that resources are not fully utilized, crowding-out of private investment by high interest rates would not occur. The point of the Keynesian school of thought on the possible effects of fiscal deficits on economic activities has been challenged by the Neo-classical school of thought on the premise that the former school ignores the significance of how fiscal deficits are financed based on the effect of this policy variable on macroeconomic performance. The Neoclassical school postulates that the manner in which deficits are financed is capable of influencing the level of consumption and investment and by extension affect economic growth.

For Nigeria scenario, the result of government role in economic activities and the achievements in economic performance have been mixed. The economy experienced growth in real output in some years and declines in others. However, the overall picture is low scoring for the country's development efforts. The economic crisis from the 1980s and early 1990s brought out vividly the distinction between growth and development. The objectives fiscal policies in Nigeria are wide-ranging. These include increase in Gross Domestic Product growth rate, reduction in the rates of inflation and unemployment, improvement in the balance of payments, accumulation of financial savings and external reserves as well as stability in Naira exchange rate. More so, policy as well as instruments applied to attain these objectives have until recently been far from adequate undue reliance which has been placed on fiscal policy rather than monetary policy in Nigeria (Darrat, 1984). Fiscal policy is considered an important variable which may determine 
changes in national income in developing countries like Nigeria. In order to stimulate the economic growth by means of fiscal policy, the country has more instruments. According to Ebimobowei (2010), these include the financing of direct investments of which the private sector would not provide adequate quantities; the efficient supply of certain public services which are necessary to ensure the basic conditions to display the economic activity and long term investments; and the financing of public activities so as to minimize the distortions to come up with the decisions to spend and invest properly in the private sector.

The fiscal policy of Nigeria has been extremely pro-cyclical with expenditures racketing out of control on the upswing of the oil price cycle. This has contributed to the observed deficit bias in the conduct of fiscal policy. One option is to put in place a fiscal policy rule. A fiscal policy rule makes sense in Nigeria, given the complete absence of a tradition of fiscal discipline. Since a fiscal rule commits government to a certain level of conduct in fiscal and budgetary management, it will help to build government credibility in fiscal management and, overtime, promote strong fiscal discipline across all tiers of government. A rule, based on oil prices, will also help address the issue of the vulnerability of all tiers of government to oil price swings and reduce the pro-cyclicality in the budget. This will allow savings to build up financial assets in periods with high oil prices that can be used to finance the desired expenditure programmes when oil prices are low (Kwakwa, 2003). Phillips (1997) critically analyses the Nigerian fiscal policy between 1960 and 1997 with a view of suggesting workable ways for the effective implementation of Vision 2010. He observes that budget deficits have been an abiding feature in Nigeria for decades. He notes that except for the period 1971 to 1974, and 1979 , there has been an overall deficit in the federal Government budgets each year since 1960 to date. He asserted that the chronic budget deficits and their financing, largely by borrowing, have resulted in excessive money supply, worsened inflationary pressures, and complicated macroeconomic instability, resulting in negative impact on external balance, investment, employment, and growth. He, however, contends that fiscal policy will be an effective tool for moving Nigeria towards the desired state in 2010 only if it is substantially cured of the chronic budget deficit syndrome it has suffered for decades.

As noted by Babangida (1993), the lack of fiscal discipline is the bane of our economy. In spite of realized revenues being above budgetary estimates, extra budgetary expenditure has been rising so fast and resulting in a bigger deficit. To say the least, this is a sobering revelation and there is need to ensure that the deficit is not only minimized but eventually eliminated. The practice of financing the fiscal deficit through the banking system, especially the Central Bank's Ways and Means facility, results in rapid growth of domestic liquidity. This in turn exerts immense pressures on prices, interest rates, and 
exchange rate of the Naira. As an illustration, between 1988 and 1991, an average of 77 percent of the overall deficit was financed by the CBN. In 1992, the deficit had been largely financed by the CBN. As a direct consequence, the monetary and credit aggregates have been exceeding prescribed targets in recent years. Folorunsho and Abiola (2000) examine the long-run determinants of inflation in Nigeria between 1970 and 1998, using the econometric methods of co-integration and error correction mechanism. They found that inflation in Nigeria could be caused by the level of income, money supply, and public sector balance. The results also indicate that in the long run, exchange rate, money supply, income, and fiscal balance determine the inflation spiral in Nigeria. The study concludes that a reduction in fiscal deficits, an increase in domestic production, and a table exchange rate should be pursued as means of controlling inflation in Nigeria.

There has been a strong deficit bias and pro cyclically in fiscal policy, which has been largely driven by oil prices in 1991-1992 and 2000-2002. More so, revenue and expenditure have increased sharply. This has typically followed the scaling back of expenditures as oil prices substantially decline, though at times with a lag. According to Baunsgard (2003), experience in Nigeria illustrates the difficulties of implementing fiscal policy in an environment with highly volatile revenue flows. The resultant effect of such boom-burst fiscal policies includes spread of oil-price volatility to the stable provision of government services. This has added to the failure over the years of public spending, facilitating the diversification and growth of the economy. There is no doubt that the failure of government fiscal policies, rather than the failure of monetary policies, is the main reason why most of the past developmental programmes undertaken by the government have come to naught (Ezeoha \& Uche, 2010).

\section{Methodology}

O'Leary (2004) describes methodology as the framework which is associated with a particular set of paradigmatic assumptions that will be used to conduct the research. Allan and Randy (2005) insist that when conducting a research, methodology should meet the following two criteria: Firstly, the methodology should be the most appropriate to achieve the objectives of the research. Secondly, it should be made possible to replicate the methodology used in other researches of the same nature. Descriptive analysis of secondary data generated from Central Bank of Nigeria and IMF has been intensively used to accomplish the objectives of this write-up.

\section{Fiscal Deficits and Economic Stabilization in Nigeria}

Economic stabilization in Nigeria through fiscal deficit will be appraised with the aid of tables. These tables will indicate average fiscal deficit 
growth rate, per capita income, unemployment rate, inflation rate, and balance of payments. The following tables will be used to analyze the effect of fiscal deficit on economic stabilization in Nigeria. Economic stability is said to exist when the real gross domestic product (RGDP) (total GDP deflated for inflation) increases persistently over time. From Table 2 below, it is observed that there was persistent growth in RGDP in three successive periods, and these periods also witnessed growth in fiscal deficit. Consequently, it can be said that fiscal deficits triggered the growth of RGDP. However, these growth periods coincides with the era of oil boom. Therefore, the growth in RGDP could be attributed to increased earnings from crude oil exportation. While in 2017-2019, there was a drastic decline which must have been as a result of sharp decline in oil revenue.

Table 2. Deficit expenditure growth rate and RGDP growth rate

\begin{tabular}{|l|l|l|l|l|}
\hline Years & $\begin{array}{l}\text { Deficit } \\
\text { Expenditure(N' } \\
\text { Billion) }\end{array}$ & $\begin{array}{l}\text { Growth Rate of } \\
\text { Deficit }\end{array}$ & $\begin{array}{l}\text { RGDP } \\
\text { (in } \\
\text { millions \$) }\end{array}$ & $\begin{array}{l}\text { Growth Rate } \\
\text { of RGDP }\end{array}$ \\
\hline $1980-1985$ & -3441.01 & - & 44.917 & \\
\hline $1986-1991$ & -16555.15 & 381.11 & 25.077 & -44.17 \\
\hline $1992-1997$ & -31581.5 & 90.76 & $\mathbf{2 7 . 0 8 8}$ & $\mathbf{8 . 0 1}$ \\
\hline $1998-2003$ & -207907.75 & 558.32 & 47.528 & $\mathbf{7 5 . 4 5}$ \\
\hline $2004-2009$ & -236574.13 & 13.78 & $\mathbf{1 4 8 . 2 5 3}$ & $\mathbf{2 1 1 . 9 2}$ \\
\hline $2010-2016$ & $-\mathbf{9 0 4 9 0 7 . 7 2}$ & $\mathbf{2 8 2 . 5}$ & $\mathbf{4 5 8 . 7 0 6}$ & $\mathbf{2 0 9 . 4 0}$ \\
\hline $2017-2019$ & $\mathbf{3 , 5 8 8 . 3}$ & $\mathbf{7 4 . 7 8}$ & $\mathbf{4 5 8 . 2 8 6}$ & $\mathbf{- 0 . 0 9}$ \\
\hline
\end{tabular}

Source: Authors' computation based on World Development Indicators (2020)

Comparative analysis of the growth rate of deficit expenditure and per capita income growth rate within seven (7) years average is used in Table 3 below. Deficit spending grew by 381.11 percent between the period of 1980 1985 and 1986 - 1991. The growth rate decline to 90.76 percent between 19861991 and 1992 -1997 periods. Later, it skyrocketed to 558.32 percent between 1992 - 1997 and 1998 - 2003 era. The growth rate also declined between the period 1998 - 2003 and $2004-2009$ to 13.78 percent. It has grown by 282.5 percent between the period 2004 - 2009 and 2010 - 2016. On the other hand, per capita income has been on the upward trend within the period under review, significantly rising by 623.85 percent between 1992 and 1997, declining by 447.69 percent to 176.16 percent between 1998 and 2003 . However, the upward trend has been noticeable from 2004 - 2016 while there was drop in 2017-2019. Evidence from literature shows that if deficit expenditure is embarked upon, it is expected to have a positive effect on development indicators, and per capita income is one of them. Consequently, Nigeria's per capita income (PCI) has been growing and fluctuating within the period under review. 
Table 3. Deficit expenditure growth rate and per capita income (PCI) growth rate

\begin{tabular}{|l|l|l|l|l|}
\hline Years & $\begin{array}{l}\text { Deficit } \\
\text { Expenditure(N, } \\
\text { Billion) }\end{array}$ & $\begin{array}{l}\text { Growth Rate of } \\
\text { Deficit }\end{array}$ & PCI & $\begin{array}{l}\text { Growth Rate of } \\
\text { PCI }\end{array}$ \\
\hline $1980-1985$ & -3441.01 & - & 740.95 & - \\
\hline $1986-1991$ & -16555.15 & 381.11 & 2086.1 & 181.54 \\
\hline $1992-1997$ & -31581.5 & 90.76 & $\mathbf{1 5 1 0 0 . 3 9}$ & $\mathbf{6 2 3 . 8 5}$ \\
\hline $1998-2003$ & -207907.75 & $\mathbf{5 5 8 . 3 2}$ & $\mathbf{4 1 7 0 2 . 0 3}$ & $\mathbf{1 7 6 . 1 6}$ \\
\hline $2004-2009$ & -236574.13 & 13.78 & $\mathbf{1 3 1 6 2 6 . 6}$ & $\mathbf{2 1 5 . 6 3}$ \\
\hline $2010-2016$ & -904907.72 & $\mathbf{2 8 2 . 5}$ & $\mathbf{4 6 2 8 9 0 . 4 6}$ & $\mathbf{2 5 1 . 6 7}$ \\
\hline $2017-2019$ & $3,588.3$ & $\mathbf{7 4 . 7 8}$ & $\mathbf{1 , 1 0 4 , 5 7 7 . 8 3 3}$ & $\mathbf{5 8 . 0 9}$ \\
\hline
\end{tabular}

Source: Authors' computation based on CBN's Statistical Bulletin (2020)

From Table 4 below, within the six (6) year period of 1986 and 1991, there was a marginal decline in unemployment indicator from 10.75 percent witnessed in the preceding six year period of 1980 - 1985. However, unemployment rate has been growing since then. The inference is that deficit expenditure has not been having the desired effect on employment generation in Nigeria. Deficit spending should stimulate national output growth which will result in employment creation (reduction in unemployment). Despite the persistent growth rate of fiscal deficit, the evil of unemployment has not been tackled by deficit spending. This may be as a result of the fact that deficit spending has been skewed in favour of recurrent expenditure to the detriment of capital expenditure. As long as capital fiscal deficit is not greater than recurrent fiscal deficit, the capacity of the economy to create employment that tackles the threat of unemployment will be significantly mitigated.

Table 4. Deficit expenditure growth rate and unemployment rate

\begin{tabular}{|l|l|l|l|}
\hline Years & $\begin{array}{l}\text { Deficit Expenditure(N' } \\
\text { Billion) }\end{array}$ & $\begin{array}{l}\text { Growth Rate of } \\
\text { Deficit }\end{array}$ & $\begin{array}{l}\text { Unemployment } \\
\text { Rate }(\%)\end{array}$ \\
\hline $1980-1985$ & -3441.01 & - & 10.75 \\
\hline $1986-1991$ & -16555.15 & 381.11 & 10.31 \\
\hline $1992-1997$ & -31581.5 & 90.76 & 10.76 \\
\hline $1998-2003$ & -207907.75 & 558.32 & 15.0 \\
\hline $2004-2009$ & -236574.13 & 13.78 & 15.43 \\
\hline $2010-2016$ & -904907.72 & 282.5 & 16.36 \\
\hline $2017-2019$ & $3,588.3$ & 74.78 & 20.9 \\
\hline
\end{tabular}

Source: Authors' computation based on CBN's Statistical Bulletin (2020)

An analysis of Table 5 below shows that a growing economy needs periodic inflation, i.e., increase in the general price level of goods and services, including wages. However, for this inflation to be the desired type, it needs to be a-single digit inflation. The effect of deficit expenditure on the general price level of goods and services has been mixed during the period under review. For example, the average rate of inflation was 17.8 percent between 1980 1985, and it further grew to 19.21 percent in the 1986 - 1991 periods. The 
upward trend continued with inflation reaching an average rate of 44.8 percent in the next period (1992 - 1997). However, there was a significant drop from 44.8 percent to 11.55 percent in the $1998-2003$ era. This grew insignificantly by 0.06 percent to 11.61 percent in the period $2004-2009$, and it was averaged at 13.89 percent between the period 2010 - 2016. Also, the inflation drop by 1.68 percent in 2017-2019. It can be concluded that despite the fact that deficit spending has been growing during the period of this study, it had a mixed effect on the rate of inflation in Nigeria within the period under review. The instability noticed in the rate of inflation could be attributed to increased earnings from oil revenue coupled with unmitigated growth in money supply. When these (increasing oil revenue and growth in money supply) are not accompanied by growth in output, demand will grow faster than supply and the consequence will be inflation with its inherent negative effects.

Table 5. Deficit expenditure growth rate and the rate of Inflation

\begin{tabular}{|l|l|l|l|}
\hline Years & $\begin{array}{l}\text { Deficit Expenditure (N' } \\
\text { Billion) }\end{array}$ & $\begin{array}{l}\text { Growth Rate of } \\
\text { Deficit }\end{array}$ & Inflation Rate $(\%)$ \\
\hline $1980-1985$ & -3441.01 & & 17.8 \\
\hline $1986-1991$ & -16555.15 & 381.11 & 19.21 \\
\hline $1992-1997$ & -31581.5 & 90.76 & 44.8 \\
\hline $1998-2003$ & -207907.75 & 558.32 & 11.55 \\
\hline $2004-2009$ & -236574.13 & 13.78 & 11.61 \\
\hline $2010-2016$ & -904907.72 & 282.5 & 13.89 \\
\hline $2017-2019$ & $3,588.3$ & 74.78 & 12.21 \\
\hline
\end{tabular}

Source: Authors' computation based on CBN's Statistical Bulletin (2020)

\section{Conclusion and Policy Implications}

This write-up is a theoretical analysis of the impact of fiscal policy variables on economic growth in Nigeria. The achievement of economic growth through fiscal policy in Nigeria has remained an illusion. Obviously, the achievement of sustainable economic growth through fiscal policy in Nigeria has remained a mirage. Despite the substantial increases in government expenditure over the years, the rate of economic growth has been very low and sluggish. The poor performance of fiscal policy has been ostensibly blamed on the problems of policy inconsistencies, high level of corruption, wasteful spending, poor policy implementation, and lack of feedback mechanism for implemented policies (Omitogun \& Ayinla, 2007). This study opens the effect of fiscal policy on economic growth in Nigeria. Therefore, this study recommends monetary policy for the purpose of economic growth and stabilization. Based on the secondary data presented in the paper, Table 1 shows that Nigerian government has always relied on deficit spending to stabilize her economy which has been validated.

As seen in Table 1, for the 40 year period of 1980 to 2019, only two years recorded surpluses: 1995 and 1996 respectively. Having had 38 years of 
deficit expenditure, how has the country fared in the attainment of the objectives of fiscal deficit, which is economic growth? From the tables above, two out of the four development indicators used in this work have conformed a priori expectation. From this stand point, deficit spending in Nigeria has stimulated growth of real GDP and per capita income in Nigeria. Furthermore, unemployment and inflation have not completely conformed. These situations call for serious attention of Nigerian government, given the fact that these variables are of great importance for economic strength. The reason for the twist in unemployment could be as a result of the fact that fiscal deficit has been geared toward recurrent expenditure to the detriment of capital expenditure which has the capacity to stimulate employment.

\section{Policy Prescription}

Government should control excessive domestic credit expansion in the economy to avoid the adverse effects of fiscal deficit. To control fluctuations in money supply, price level and rate of interest, government should avoid short run devaluation and stabilize external value of currency. Government should utilize its resources properly to control deficit in meeting its expenses. Therefore, such policies should be designed that can encourage people to pay taxes and give incentives to those who avoid paying taxes. Government should decrease lenders' interest rate so that small domestic investors can invest to create employment opportunities along with increase in government revenue. In order to avoid deficit budget, the parliamentarians should reduce their personal and unproductive expenditures. The study recommends that if fiscal deficits are the essential tool of correcting short term fluctuations in the economy, then these deficits should be invested in productive and profitable projects. More especially, deficit should be invested in infrastructure to get sustainable economic growth. In Pakistan, elimination of corruption will reduce fiscal deficit and improve performance of economy.

Fiscal policy should give priority attention to capital and public investments by making them of higher proportion in gross government expenditure, thereby creating more jobs and enhancing the quality of public spending and the attainment of sustainable growth and development.

Emphasis should be on the development of basic infrastructure (e.g., transportation, energy and communication). Human capital development should be a priority. Government fiscal policy should refocus and redirect government expenditure towards production of goods and services so as to enhance GDP growth.

Government economic policies should also focus on diversification of the economy to enhance the performance of the non-oil sector, so as to create more jobs in this sector. The government should avoid unnecessary borrowings and ensure that existing debts are properly serviced as at when 
due. The government should ensure that policy inconsistency is minimized and policy reversals are properly checked for both short and long run effects on the economy. Government should fight the problem of corruption because without a reduction of the level of corruption in the country, fiscal policy components will not achieve the required level of economic growth in Nigeria. There is need for an improvement in government expenditure on health, education, and economic services, as components of productive expenditure, to boost economic growth.

\section{References:}

1. Abata, M. A., Kehinde, J. S. \& Bolarinwa, S. A. (2012). Fiscal/Monetary policy and economic growth in Nigeria: A theoretical exploration. International Journal of Academic Research inEconomic and Management Science, 1(5), 75-88.

2. Abdullah, H. A. (2000). The Relationship between Government Expenditure and Economic Growth in Saudi Arabia. Journal of Administrative Science. 12(2):173 - 191.

3. Abdurrauf, I. B. (2015). Fiscal policy and economic development in Nigeria. Nigeria Journal of Economics and Sustainable Development, 6(7), 150-159.

4. Adefeso, H. A. \& Mobolaji, H. I. (2010). The fiscal policy and economic growth in Nigeria: further empirical evidence. Pakistan journal of social sciences, 7(2), 137142.https://doi.org/10.3923/pjssci.2010.137.142

5. Ajisafe, R.A. \& Folorunsho, B.A. (2002). The Relative Effectiveness of Fiscal and Monetary Policy in Macroeconomic Management in Nigeria. The African Economic and Business Review,3(1). Spring

6. Akanni, K. A. \& Osinowo, O. H. (2013). Effect of fiscal instability on economic growth in Nigeria. Advances in Economics and Business, 1(2), 124-133.

7. Agu, S. U., Idike, A. N., Okworlfeoma, M. I. \& Ugwunta, D. (2014). Fiscal policy operation and economic growth in Nigeria: emphasis on various components of public expenditure. Singaporean Journal of Business Economics and Management Studies, 2(12), 1-12.

8. Allan, AJ. \& Randy, LJ. (2005). Writing the Winning Thesis or Dissertation. A Step-by-Step Guide, Corwin Press, California.

9. Appah, E. (2010). The relationship between fiscal policy and economic growth in Nigeria. International Journal of Economic Development, Research and Investment, 1(2-3), 37-47.

10. Arestis, P. (2009). New consensus macroeconomics: a critical appraisal. Working paper series, paper no. 564. The Levy economics 
institute of Bard College, University of Cambridge. https://doi.org/10.1007/978-0-230-29166-9_6

11. Babalola, S. J. \& Aminu, U. (2015). Fiscal policy and economic growth relationship in Nigeria. International Journal of Business and Social Science, 2(17), 244-257.

12. Babalola, S. J. \& Aminu, U. (2015). Fiscal policy and economic growth relationship in Nigeria. International Journal of Business and Social Science, 2(17), 244-257.

13. Baunsgard, T. (2003). Fiscal Policy in Nigeria: Any Role for Rules. International Monetary Fund Working Paper.

14. Baxter, M. \& King, R. G. (1993). Fiscal policy in general equilibrium. American Economic review, 83(3), 315-334

15. Byiabani, J. \& Mohseni, R. (2014). Fiscal policy and economic growth: a case study of Iran. Kuwait Chapter of Arabian Journal of Business and Management Review, 4(1), 48-57.

16. Bogdanov, B. (2010). Cyclicality of Fiscal Policy over Business Cycle: An Empirical Study on Developed and Developing Countries. Agency for Economic Analysis and Forecasting, Working paper Series

17. Chakraborty, P. \& Chakraborty, L. S. (2006). Is fiscal policy contra cyclical in India: An empirical analysis, MPRA Paper No. 7604. Retrieved February 11, 2010, from http://mpra.ub.unimuenchen.de/7604/1/MPRA_paper_7604.pdf.

18. Chang, T. \&Ho, YH. (2002). A Note on testing tax-and-spend, spendand-tax or Fiscal Synchronization: The Case of China, Journal of Economic Development, 27(1)

19. Cyril, U.M. (2016). The effect of fiscal policy on economic growth in Nigeria. Journal of Finance and Accounting, 4(3), 140-145. https://doi.org/10.11648/j.jfa.20160403.16

20. Darrat, A.F. (1984). The Dominant Influence on Fiscal Actions in Developing Countries. Eastern Economic Journal. X(3): 271-284.

21. Enache, C. (2009). Fiscal policy and economic growth in Romania. Annales Universitais Apulensis Series Oeconomica, 11(1), 502-512.

22. Engen, E.M. \& Skinner, J. (1992). Fiscal policy and economic growth. NBER, Working Paper no. 4223. African Economic Research Consortium, Nairobi, Kenya. https://doi.org/10.3386/w4223

23. Ezeoha, A. \& Uche, C. (2010). Rethinking Monetary and Fiscal Policies in Nigeria.

24. Fatás, A. \& Mihov, I. (2001). The effects of fiscal policy on consumption and employment: theory and evidence. European Summer Symposium on International Macroeconomics, Tarragona mimeo, INSEAD. 
25. Folorunso, B.A. \& Abiola, A.G. (2000). The Long - run Determinants of inflation in Nigeria (1970 - 1998). The Nigerian Journal of Economic and Social Studies, 42(1): 37 - 52.

26. Gemmell, N. \& Au, J. (2012). Government size, fiscal policy and the level and growth of output: a review of recent evidence. The Working Papers in Public Finance, working paperno.10/. Published by the Victoria Business School, University of Wellington, New Zealand. https://doi.org/10.2139/ssrn.2199225

27. Havi, E.D.K. \& Enu, P. (2014). The effect of fiscal policy and monetary policy on Ghana's economic growth: which policy is more potent? International Journal of Empirical Finance, 3(2), 61-75.

28. Imoisi, A. I. (2013). An appraisal of fiscal policy measures and its implication for growth of the Nigerian economy. Journal of Advances in Management and Applied Economics, 3(4), 193-204.

29. Ismihan, M. \& Özkan, F.G. (2012). The Golden Rule of Public Finance: A Panacea Ekonomitek, 1(2) May / Mayis.

30. Ilzetzki, E., Mendoza, E. G., Vég, C. A. (2011). How big (small?) are fiscal multipliers? International Monetary Fund, Working Paper no. WP/11/52, IMF Research Department.

31. Jemec, N., Kastelec, A.S. \& Delakorda, A. (2011). How do fiscal shocks affect the macroeconomic dynamics in the Slovenian economy? Izdajabankaslovenije, zbirkoprikazi inanalizepripravlja in urejaanalitskoraziskovalni center bankeslovenijeUporaba in objavapodatkov in delovbesedila je dovoljena z navedbovira, Številka 2, Letnik XVII. German.

32. Kilindo, A.A.L. (1997). Fiscal operation, money supply and inflation in Tanzania. AfricanEconomic Research consortium, AERC research paper sixty-five, Nairobi, Kenya.

33. Kwakwa, V. (2003). A Framework for Assessing Fiscal Sustainability: Application to Nigeria, Third Annual Monetary Policy Conference Proceedings on Issues in Fiscal Management: Implications for Monetary Policy in Nigeria, 11-12 December 2003. Lagos, Central Bank of Nigeria Publications.

34. Lozano, I. (2008). Budget Deficit, Money Growth and Inflation: Evidence from the Colombian Case, Borradores de Economia, 537, 126.

35. Maku, O.E. (2015). Fiscal policy and economic growth: a study on Nigerian economic perspective. Journal of Economics and Sustainable Development, 6(15), 86-92.

36. Mansouri, B. (2008). Fiscal policy and economic growth: Egypt, Morocco and Tunisia Compared. UNECA Conference on 
Macroeconomic Policy, Productive Capacity and Economic Growth in Africa, Addis Ababa, Ethiopia.

37. Matthew, K. O. (2011). Fiscal policy and economic growth in South Africa. Journal of Economic Studies, 38(5), 604-618. https://doi.org/10.1108/01443581111161841

38. Mitchell, D. (2002). The correct way to measure the revenue impact of changes in tax rates, manuscript available at http://www.heritage.org/Research/Taxes/BG1544.cfm.

39. Monacelli, T. \& Perotti, R. (2006). Fiscal Policy, the Trade Balance, and the Real Exchange Rate. The Economic Journal, 437 - 461

40. Musa, Y., Asare, B.K. \& Gulumbe, S.U. (2013). Effect of monetaryfiscal policies interaction on price and output growth in Nigeria. CBN Journal of Applied Statistics, 4(1), 23-55.

41. Nathan, PA. (2012). The impact of fiscal policy on the Nigerian economy. Journal of International Review of Social Sciences and Humanities, 4(1), 142-150.

42. Neaime, S. (2008). Twin Deficits in Lebanon: A Time Series Analysis, IFE Lecture and Working Paper Series No 2Beirut Institute of Financial Economics, American University of Beirut.

43. Nelson, M.A. \& Singh, R.D. (1998). Democracy, economic freedom, fiscal policy, and growth in LDCS: a fresh look. Economic Development and Cultural Change, 46(4), 677696.https://doi.org/10.1086/452369

44. Ogbole, F.O., Amadi, S.N. \& Essi, I.D. (2011). Fiscal policy: its impact on economic stabilisation in Nigeria. Journal of Economics and International Finance, 3(6), 407-417.

45. Okpanachi, U. M., \& Abimiku, C. A. (2007). Fiscal deficit and macroeconomic Performance: A survey of theory and empirical evidence. In P. Ogiji (Ed.), the Nigerian economy: Challenges and directions for growth in the next 25 years (pp. 3-34).

46. O'Leary, Z. (2004). The essential guide to doing research". Sage. Walliman, N. S. \& Walliman N. (2011) "Research methods: the basics" Taylor and Francis.

47. Omitogun, O. \& Ayinla, T.A. (2007). Fiscal Policy and Nigerian Economic Growth. Journal of Research in National Development. 5 (2) December.

48. Onyemaechi, J. O. (2014). Impacts of fiscal policy components on economic growth in Nigeria: an empirical trend analysis. Kuwait Chapter of Arabian Journal of Business and Management Review, $4(1), 24-31$. 
49. Osinowo, O.H. (2015). Effect of fiscal policy on sectoral output growth in Nigeria. Journal of Advances in Economics and Business, 3(6), 195-203.

50. Perotti, R. (2002). Estimating the effects of fiscal policy in OECD countries. International seminar on macroeconomics, working paper series, working paper no. 168, European Central Bank.

51. Philips, A.O. (1997). Nigerian Fiscal Policy, 1998 -2010. Nigerian Institute of Social Economic Research (NISER), Monograph Series No. 17, Ibadan

52. Ravn, S. H. \& Spange, M. (2012). The effects of fiscal policy in a small open economy with a fixed exchange rate: the case of Denmark. Working Paper series of Denmark's National Bank, Copenhagen Denmark.

53. Saleh, A. S. (2003). The Budget Deficit and Economic Performance: A Survey, Working Paper 03-12, Department of Economics, University of Wollongong.

54. Sargent, T. \& Wallace, N. (1981). Some Unpleasant monetarist arithmetic, Federal Reserve Bank of Minneapolis Quarterly Review 5: 117.

55. Stadler, M. (2003). Innovation and Growth: The Role of Labor Force Qualification, Wirtsc!7aftswissenscJJaftlicfJe Fakult ·at der Eberhard KarlsUniversit · "at T"ubingen.

56. Tanzi, V. \& Howell, H. Z. (1997). Fiscal policy and long-run growth. International Monetary Fund Staff Papers, 44(2), 179-209. https://doi.org/10.2307/3867542

57. Tchokote, J. (2001). Macroeconomics of Fiscal Deficits in Cameroon. Being a Ph.D. Thesis Proposal presented to the Department of Economics. Ibadan: University of Ibadan

58. Yadav, S., Upadhyaya, V. \& Sharma, S. (2010). Impact of fiscal policy shocks on the Indian economy. MPRA Paper No. 34071, Munich Personal RePEc Archive.

59. Zhattau, V. S. (2013). Fiscal policy as an engine of economic growth in Nigeria. AFRREV IJAH, an International Journal of Arts and Humanities, 2(2), 282-298. 